\title{
Parkinson's disease before Parkinson, Vilnius 1814
}

Valmantas Budrys MD PhD

J R Soc Med 2005;98:178-179

Parkinson's disease as a separate illness was defined by James Parkinson in his famous work An Essay on the Shaking Palsy published in 1817. Clearly the condition had existed since ancient times. Parkinson's special contribution was to describe and collate the features in dynamic terms, by observing affected individuals in the street and as they performed ordinary actions. He also made the distinction, previously unclear, between resting tremor and action tremor. In 1880 Jean-Marie Charcot completed the full clinical picture, and the artist Paul Richer provided drawings to illustrate typical features - the first known depictions of Parkinson's disease.

In previous works of art there is no difficulty in spotting isolated elements of Parkinson's disease - the inexpressive face, the bent posture - but one can hardly be sure of the diagnosis. An engraving made in Vilnius, three years before Parkinson's account, is an impressive exception (Figure 1). It is by Isidorus Weiss (1774-1821), a German-born artist who worked for a few years in Lithuania and taught in the Department of Engraving at Vilnius University. ${ }^{1}$ His Selling of the Smoked Hams, executed in 1814, shows the daily scene in a small shop with three persons - two young ladies on the right and the elderly ham-seller on the left. An inscription at the bottom of the print reads as follows:

Herr Kulik ist ein braver Mann,

Er liefert gule Schinken;

Es kauffe ver da kauffen kann,

Sie machen Lust zum Trinken.

Mister Kulik is a brave man,

He sells smoked hams;

This is much respected by these buyers,

You feel pleasure having a snack while drinking.

Let us look closely at the seller. Mr Kulik is about sixty and his posture is bent. His right arm, flexed, clutches the neckband of his garment; the left, less flexed, seems to be reaching for money on the table. His smile is constrained, the face expressionless and his posture stiff and bent;

Clinics of Neurology and Neurosurgery, Vilnius University Faculty of Medicine, Vilnius University Santariskiu Klinikos Hospital, Santariskiu 2, LT-08661 Vilnius, Lithuania

E-mail: valma@takas.It

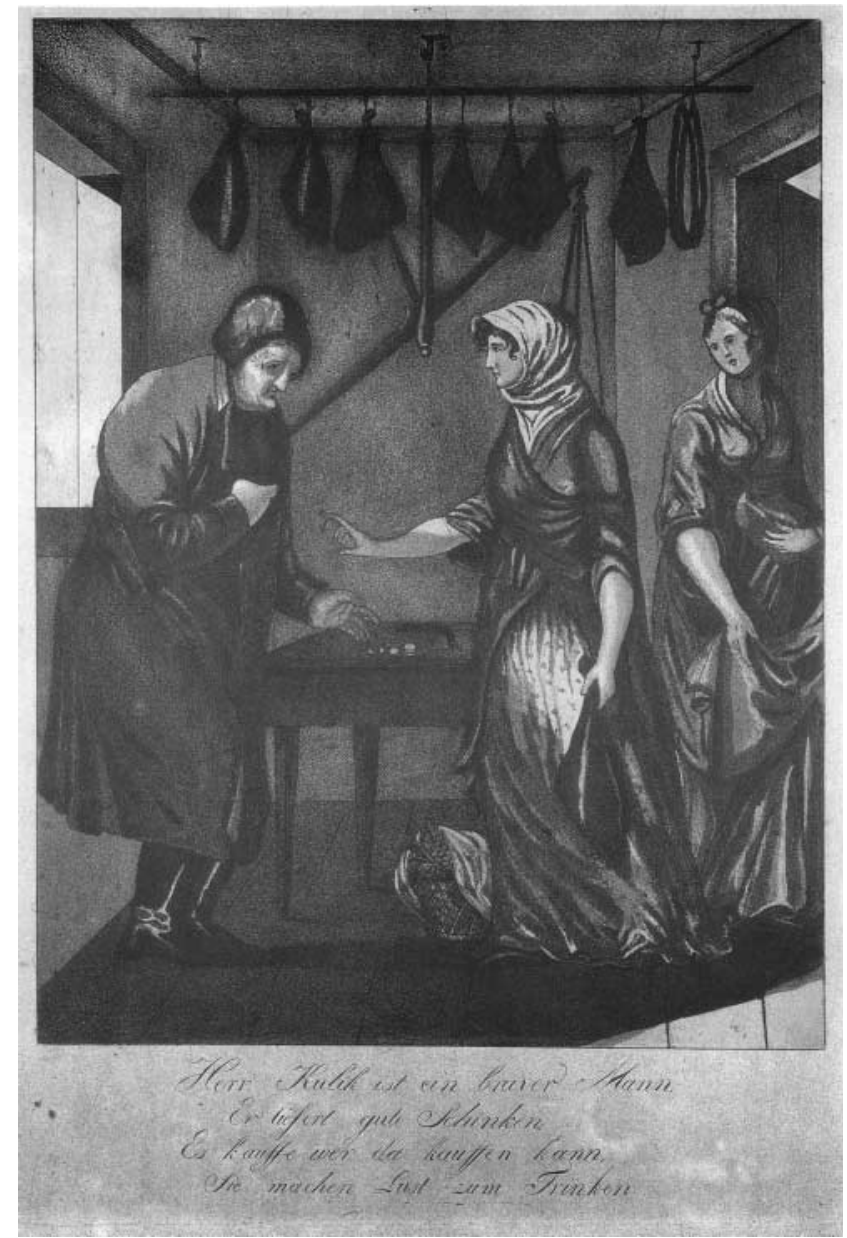

Figure 1 Selling of the Smoked Hams, Isidorus Weiss, 1814. [Reproduced by permission, Collection of Graphic Art Study, Vilnius Academy of Art, Vilnius, Lithuania]

compare the lively faces and expressive stances of the two young ladies.

Key features of Parkinson's disease are stooped posture, bradykinesia, resting tremor, rigidity and instability. ${ }^{2,3}$ Regarding posture, compare the portrayal of Kulik with one of Paul Richer's classic drawings of parkinsonian patients (Figure 2). If anything, Weiss's depiction is the more impressive. Bradykinesia shows itself in dysarthria, micrographia and hypomimia with mask-like face. The face of the ham-seller is typical. Resting tremor $(4-7 \mathrm{~Hz})$ mainly affects the limbs. Could it be that Kulik is gripping the neckband with his right hand to suppress unpleasant tremor? 


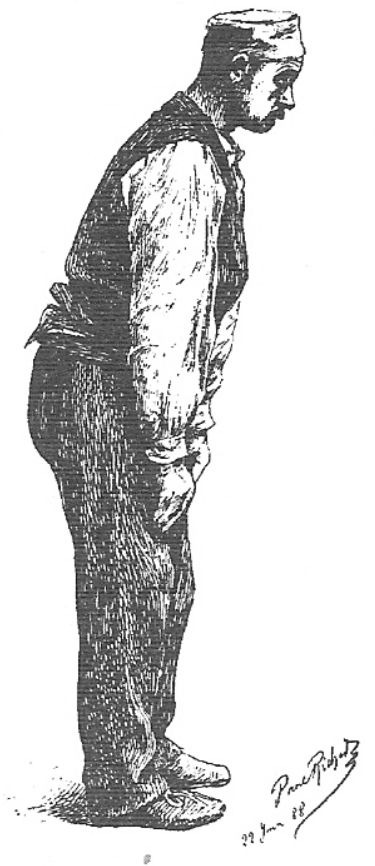

Figure 2 Parkinsonian patient [Paul Richer, 1888]

Perhaps, but the left hand is more striking. Parkinsonian tremor is commonly likened to the action of pill-rolling, but some textbooks see a resemblance to money-counting. This could be a static depiction of tremor; and, if so, how prescient the artist! Postural instability — a tendency to lurch backwards or forwards and to fall-is characteristic of the advanced stage of Parkinson's disease. Notice in the picture the lady's right hand extended towards the ham-seller, perhaps to stop him falling forwards. (Another interpretation is that his posture denotes freezing, also a feature of advanced disease. 'Don't worry,' she may be saying, as he experiences an involuntary arrest of movement when showing his customers to the door.) The last element, rigidity, added only by Charcot in 1880, cannot be recognized in the picture.

It is unusual to see, in a sympathetic portrayal such as this one, such obvious manifestations of disease. Either this picture was done from life or the artist was particularly impressed by what he had seen on some previous occasion. It is curious to think that, almost at the same time that James Parkinson was making his famous observations from the window of his house in London, Isidorus Weiss was noting similar features in the proprietor of a Vilnius dollyshop.

\section{REFERENCES}

1 Cibulskas V, ed.Vilniaus dailës akademijos senoji grafika [Vilnius Art Academy Old Graphic Collection]. Vilnius: Vilniaus dailës akademija, 1993

2 Jankovic J, Stacy M. Movement disorders. In: Goetz ChG, Pappert EJ, eds. Textbook of Clinical Neurology, 6th edn. Philadelphia: WB Saunders, 1999:655-79

3 Abnormalities of movement and posture due to disease of the basal ganglia. In: Adams RD, Victor M, Ropper AH. Principles of Neurology. New York: McGraw Hill, 1997:64-83 